\title{
The great polarized game in the Indian Ocean: Options for US, China and Pakistan
}

\author{
Sharin Shajahan Naomi | Syed M. Saad Zaidi* | Adam Saud \\ 1. Department of Gender Studies, Asian University for Women, Chittagong, Bangladesh. \\ 2. Department of Humanities and Social Sciences, Bahria University, Islamabad, Pakistan. \\ *Corresponding Author Email: saadz93@ hotmail.com
}

\begin{abstract}
Indian Ocean (IO) has occupied an overlapping space of political concern and maritime security due to increasing geo-strategic importance in the region. A competition has been noticed amongst key littoral states in the IO, particularly among United States, India and China. In this competing game, United States is found to be proactively supporting India to expand its influence on IO. On the other hand, China is developing trade and military relationship with other countries including Pakistan to demonstrate leverage on the IO region. This paper sheds light into this great polarized game and its implications for Pakistan. The study uses secondary data and adopts a critical approach largely based upon 'realist' paradigm to analyse and understand the role of the aforementioned key actors in the political developments of the region The study reveals that both India and China, are competing ferociously and forming alliances (India with USA and China with Pakistan) to establish regional hegemony. This competition, in turn, has greatly politically polarized the region and threatened peace and stability. In this context, Pakistan needs to carefully develop its strategy which will serve its aspiration to have a positive peaceful image in the global politics and serve strategic national interest.
\end{abstract}

\section{Article History}

Received:

October 21, 2020

Revised:

December 3, 2020

Re-revised:

August 14, 2021

Accepted:

September 24, 2021

Published:

November 22, 2021

Keywords: politics of Indian Ocean, geopolitical paradigm shift, grand strategy, Sino-Indian strategic competition, Belt and Road Initiative, United States, China, Pakistan.

How to Cite: Naomi, S. S., Zaidi, S. M. S., \& Saud, A. (2021). The great polarized game in the Indian Ocean: Options for US, China and Pakistan. Liberal Arts and Social Sciences International Journal (LASSIJ), 5(2), 236-249. https://doi.org/10.47264/idea.lassij/5.2.16

Publisher's Note: IDEA PUBLISHERS (IDEA Publications Group) stands neutral with regard to the jurisdictional claims in the published maps and the institutional affiliations.

Copyright: @ 2021 The Author(s), published by IDEA PUBLISHERS (IDEA Publications Group).

Licensing: This is an Open Access article published under the Creative Commons AttributionNonCommercial 4.0 International License (http://creativecommons.org/licenses/by-nc/4.0/) 


\section{Introduction}

As the third largest ocean, Indian Ocean (IO) span over an area of 73,556,000 square kilometers covering Asia, Africa and Australia. As a connecting route between the Pacific and the Atlantic oceans, with important international choke points like the Strait of Hormuz, Bab el Mandeb, Horn of Africa, Suez Canal via Red Sea and the Strait of Malacca, Indian Ocean Region (IOR) contains reserves of over $65 \%$ of the world oil and $35 \%$ of the gas reserves. Its geo political significance has made it the epicenter of maritime economy and military presence of the world powers with growing strategic competition among the external powers and the littoral states.

In modern history, geopolitically, majority of the geo-strategic conflicts among the Great Powers took place within these two the Atlantic ocean and pacific ocean (Jeffrey, 2019). Compared to that turmoiled history, the IOR remained relatively calm. The IO has always been a critical waterway for the trade and commerce activities throughout the history dating back to the Roman era. Since the commencement of the Cold War, the IO's geo-strategic importance began to grow day by day, primarily due to the convergence of interests of geopolitics and the energy security from multiple countries with competing interest in the global politics (Kowalski, 2019).

Besides, the American, British, Russian, Chinese, India, Pakistan navies maintain a strong military presence in the IO. United States (US) - the current Superpower, China - rapidly rising power, and India - the IO's largest littoral state fiercely compete for dominance the IOR (Hornat, 2016). The power struggle between USA and China substantially grew after 2008's financial crisis when China's hard edged Asia's policy and USA's 're-balancing' of strategic interest from Europe and the Middle East toward East Asia encountered each other (Zaidi et al., 2020). The US considered its major security concerns in terms of ongoing conflicts and tensions in the littoral states of the Middle East and China's increasing presence in the ocean and took India as major partner which is a rising power and keen to balance China's forays into the area of IOR for self-interest (Hughes, 2016).

While the USA embraced India as a trusted ally in IOR, Pakistan's importance became profound to China as strategic partner for power play in IOR and beyond (Younus, 2020). Pakistan has promoted China's growing interests in this IO in return of economic, technological and military assistance. China initiated multi-trillion dollars 'Belt and Road Initiative (BRI)', two new trade routes connecting China with rest of the world with an aim to reduce its reliance on the Malacca strait off the coast of Singapore which has been a major US ally, and create an alternative market beyond borders of China and to boost economies of the country's central provinces (Jie \& Wallace, 2021). To recreate this old Silk Road, which once flourished between $207 \mathrm{BCE}$ and $220 \mathrm{CE}$, China, one of the most important partner countries for China is Pakistan. Having borders with China's Xinjiang Province in the north, Pakistan provides China with a potential corridor through the mountain highway Karakoram to the seaport at Gwadar in Baluchistan on the IO (Farr, 2017; Rehman et al., 2018). As China's serious opponents to this initiative, New Delhi has consistently opposed this initiative since a key part of project would passes through Pakistan-held Kashmir (Ahmad et al., 2020; Hindustan Times, 2021). 
Pakistan's strategic importance to China lies in increasing the USA-China rivalry and Pakistan's historical and political role as opponent of India. Although China's powerful role in the UN Security Council, and its willingness to offer military and financial assistance has made Pakistan deepening its dependency on China; however, how far this alliance could assure Pakistan in maintaining domestic stability and regional power demonstrations, that is questionable (Idrees et al., 2017; Ali, 2020). Pakistan's position in this battle for ascendancy in the IOR is crucial, and subject to critical examination. The growing polarization between USA-India bloc and China expands over IOR and captures trade, commerce, military interest and regional countries like Afghanistan. Although Pakistan's allegiance to China will bring tremendous socio-economic and political fruits for Pakistan due to political, economic and financial interest like 'China-Pakistan Economic Corridor' (CPEC) and China's role in the 'United Nations Security Council' (UNSC) and other multilateral organizations. It will marginalize Pakistan's relations with the US, the current hegemon and overshadow its already tensed relations with India. In the context of global polarizations, Pakistan needs to carefully gauge its strategic gain from reliance on a single super power and navigate unpredictable terrains of international politics and regional power dynamics to demonstrate its agency over IOR with a greater cause of peace and stability .

\section{Rationale}

Most of the works on political dynamic of IOR have a heavily bias towards the interest of India and the USA without understanding the crucial role of Pakistan. Surprisingly, even though Pakistan's geo strategic location within the IOR is of immense importance, there exists little scholarly literatures to crucially evaluate Pakistan's role in the politics of the IO. Lastly, the role of Pakistan in the geopolitics of the IOR is barely discussed in the available literature. Whereas Pakistan is coupled with China in this politics, especially after the materialization of CPEC. Pakistan is seldom discussed as an influential actor of the IOR. If one objectively analyzes the politics of the IO, after India, Pakistan is undoubtedly the most critical state in this region owing to its geostrategic location which is in proximity to India, China, Iran, the Arabian Sea and Straits of Malacca.

Furthermore, there exists a dominant narrative in the existing literature that drives the reader/researcher to believe that the nature of the Chinese buildup in the IO to be imperialistic/hegemonic and Pakistan as a part of unholy alliance with China . To the contrary, many Chinese high-ranking leaders have time and again clarified that China's naval buildup in the region predominantly focuses upon securing China's trade and commerce activities through the IOR. In these literatures, positive role of China vis-à-vis the IOR's socio-economic development is not only completely sidelined, but also negatively showcased as 'debt-trap' diplomacy to de-facto control of the foreign policies of other states. In addition, prevailing literatures mostly portrays the US as an agent of peace and stability in the IOR, working for the greater good and promoting socio-economic development of the region. However, The USChina confrontation, which some security experts term as 'Cold War 2.0,' is destabilizing and polarizing the region, which these literature does not highlight. However, these literatures hardly tried to accept Pakistan's potential roles to develop peace and stability and address Pakistan's strategic interest, specially in terms of supporting China. 


\section{Research methodology}

The current research is descriptive, analytical and qualitative in nature. It predominantly explains and critically analyses the available information and the facts about the subject. The data is primarily based on secondary sources like books, research papers, magazine articles, media expert discussions and newspaper reports, as it was direly difficult to access or collect the primary data due to the scarcity of resources and time. Similar to the frequently conducted security and doctrinal studies, this research addresses the subject in its completeness according to available data; it sheds light on the all-important players vis-à-vis politics of the Indian Ocean, how their policies affect the geopolitics of the IOR, and how it affects Pakistan's posture in the region as well as in global context.

\section{Growing Political Polarisation of the IO: Analysis and discussion}

\subsection{IO's geo-strategic significance and role of Pakistan}

The IO is the third biggest ocean of the world which covers almost 20 percent of the earth's sea surface (Cordesman \& Toukan, 2014). Its strategic importance lies in its geographical characteristic which connects key parts of the world i.e., Europe, Africa, South-Asia and Middle East.

According to Sengupta (2020, $1^{\text {st }}$ paragraph),

"The Indian Ocean matters today, arguably more than ever. It is a major conduit for international trade, especially energy. Its littoral is vast, densely populated, and comprised of some of the world's fastest growing regions. The Ocean is also a valuable source of fishing and mineral resources. And yet its governance and security are under constant threat of being undermined, whether by nonstate actors such as pirates, smugglers, and terrorists, or by furtive naval competition between states."

Sengupta (2020, $3^{\text {rd }}$ paragraph) further states,

"The energy flows through the Indian Ocean are of particular consequence. Some 36 million barrels per day - equivalent to about 40 per cent of the world's oil supply and 64 per cent of oil trade - travel through the entryways into and out of the Indian Ocean, including the Straits of Malacca and Hormuz and the Bab-el-Mandeb"

In contemporary times, the IOR has become a place for critical geopolitical conflicts among North Korea, China, India-Pakistan, Iran, Saudi Arabia and Israel (Ansari, 2019). It is said that whoever controls the IO will dominate Asia (Mahan, 1987). Perhaps this conflict would be dominated by an unilateral political and military power interest of USA and its varied degrees of political affiliation and confrontation with different littoral states of IO unless China would arise as a dominant global player after post-2008's financial meltdown. Historical ambivalent relationship between China and India and tensed encounters between USA and China have 
deepened the fissures among possible collaboration among these three countries for bringing stability and security in IOR. Even though Pakistan is a primary littoral state in the IOR, it is not a member of the IO Rim Association (IORA) or the Bay of Bengal Multi-Sectoral Technical and Economic Cooperation (BIMSTEC). Pakistan location for IOR geo political equation is extremely important since is at the cusp of the Arabian Sea which close to the Strait of Hormuz (Farid, 2020).

In capturing the trade routes and expanding military power and surveillance for maritime security, Pakistan could offer strategic routes for connection and military collaboration. However, Pakistan's possible roles as a full participant and agent in this region are not fully appreciated from India-USA due to Pakistan's not-so-transparent role in combating extremism in its own soil and Afghanistan (Yaqoob \& Sattar, 2021). Its reluctance to solve Kashmir issue in the way India wants has also been enormous hurdle for creating dialogue with India for IOR's issue. On the other hand, China, as a less bothered country in other country's internal affairs and apparently, less interest to give a though to global war against terrorism, offered assistance and assurance to Pakistan as a partner of geopolitical game in IOR. Relying primarily through trade and invest to build a sustainable relationship with Pakistan, China is moving faster than ever to claim its dominance over IOR. The join drill between the navies of Pakistan and China in the Arabian Sea near India's western coast in 2020 sends a message to the competing parties in IOR region that the great game in IOR is not going to be only IndiaUSA's domain.

\subsection{Towards a great game: India, China and the US}

India, China and the USA tripolar competition to sustain geopolitical leverage in the IOR could be perceived as a great game of power through developing competing trade and military networks establish hegemony over IOR (Hannah, 2019). In order to understand, how India and USA are competing with China in this power play, we need to trace the strategic, military and trade interest if these countries with other countries, which apparently show naïve and purely bilateral in nature. However, beneath these activities, there is plan to claim necessary commands over the regions which are related to IOR through geo political position and interest. These plans are necessary to be understood in nuanced way to identify Pakistan's position in this highly polarized power politics.

In 1945, Indian statesman Panikkar wrote , "India and the Indian Ocean," which provided an account of the IO's strategic importance for the subcontinent (Panikkar, 1945). According to Panikkar (1945), the oceanic space will determine India's security and defense. In the latter part of the first decade of the twenty-first century, India's policy regarding the IOR became quite vibrant and active. The Indian government's maritime security strategy has taken into account essential choke points and the importance of strengthening Indian Navy's increasing militarized footprint.

India, having a 7,500 km coastline with the IO, and rims at both the eastern and western sides, up till now has constructed 12 major and 205 minor seaports to strengthen its influence and command over the IOR (Jaishankar, 2016). It is interest to be rising a dominant power IOR 
escalated during Modi's government era. In 2014, Prime Minister Modi, announced the 'Sagarmala' plan, which intends to double India's major seaports to facilitate trade (SagarMala - Concept \& Objectives, n.d.). India's strong diplomacy, its big market and emerging naval force have been lucrative for some countries for joining in partnership with India and let India use their military base in IOR. For instance, Indonesia allowed India to use 'Sabang port,' Oman gave access to' Duqm port,' the US agreed to let India use 'Diego Garcia,' and France allowed the use of its 'Reunion Island base' (Thakker, 2018).

Furthermore, an informal 'Quadrilateral Security Dialogue' or the 'Quad' among India, the US, Australia and Japan is on the way to tighten maritime security, trade relations and military partnership in Indo-Pacific region (Chinoy, 2019). It is obvious that rise of China will make them closer. India has been able to establish strategic alliance with Iran and to develop a deepwater port and free-trade zone in Chabahar through which Iran will get direct access to the IO for Iran (Tabrizi \& Dave, 2017). Chabahar port will serve the purpose of transit route to Afghanistan and central Asia. The Chabahar Port in the Sistan-Balochistan province of Iran is going to be the only Iranian entity that has been spared from US sanctions presenting the value of closeness of the Indo-US ties to Iran (Hassan, 2019). From the equation of political polarization in IOR, this port could balance out growing Sino-Pakistani cooperation by strengthening India- Iran ties (Aliasgary \& Ekstrom, 2021).

In 2017, India and Japan announced the formation of the 'Asia-Africa Growth Corridor' - "a collaborative vision between India and Japan to promote development, connectivity, and cooperation between Africa and Asia (AAGC) (Panda, 2017). It is considered that the $\$ 40$ billion AAGC can be an alternative strategic development alliance to Belt and road Initiative by China (Chaudhury, 2017). Through the AAGC, India will get the scope to develop cordial ties with 54 African states and strengthen its political leverage in the 'United Nations General Assembly (UNGA)'.

India is one of the most influential members of Ocean Rim Association (IORA) or the Bay of Bengal Multi-Sectoral Technical and Economic Cooperation (BIMSTEC), the platform for demonstrating diplomatic power and identifying scope for liaison with other countries for issues related OR. The current Modi government has been persistent and committed in calming down China's potential influence in the IOR through engagement of third states (e.g. Bangladesh). By signing the US-India Joint Strategic Vision Statement for the Asia-Pacific and IO in 2015, India has expanded its engagement with the US in terms of the maritime security, navy-to-navy partnership, opposing terrorism and regional dialogue among the stakeholders of IOR (Gul et al., 2021).

The Unites States has been a strong ally of India for exercising control over IOR region. With the rise of the new century, the IRO's importance started to grow day by day to USA. The growing-importance of the IOR was reiterated US Naval document in 2007 clearly stating that IOR will be of great interest to the US in the future (Dombrowski \& Winner, 2014). In 2011, Hilary Clinton, the then US Secretary of State, said that "the future of world politics will be decided in Asia, neither Iraq nor Afghanistan; and the US will be in a dominating position" (Clinton, 2011). Importance of the IOR to US began to grew from there. The US invasion of 
Afghanistan in 2001 made the IOR of a pivotal importance to the US. Later, the rapid rise of China came into the limelight of geo-politics which forced the US to strengthen its political maneuver in the IOR.

In 2011, the US initiated the 'Pivot to Asia' policy to encounter China's growing geo-economic rise and geo-military influence through exerting influence on the Asia Pacific region. Later, in 2017, the Trump regime issued the 'National Security Strategy' and in 2018, 'National Defense Strategy,' which for the first time, termed China to be a 'revisionist state' and a threat to the 'uni-polar moment' led by the US (Brookings, 2017; Grieco, 2018). The US blamed China to be inducing 'debt-trap diplomacy' that offered developing countries huge amounts of debts with flexible conditions (Glosserman, 2020). An argument that got some credibility when Mahathir Mohamed, the then Malaysian Prime Minister, not only scraped \$23 billion worth BRI projects, but also cautioned China against propagating a new kind of colonialism (Hornby, 2018). According to the USA'contention, this debt-trap diplomacy will be instrumental in asserting China's hegemony over the regions. Furthermore, to counter BRI, the US established a \$300 million 'security assistance' fund for the Indo-Pacific region (Reuters Staff, 2018b). The US's 'Overseas Private Investment Corporation' (OPIC) has already invested \$3.9 billion within the Indo-Pacific region (Ford, 2020). The US announced to work with Japan and Australia to provide alternatives to Chinese investment (Ford, 2020).

China is one of the most threatening actor in India and the USA's partnership's vision for dominating the IOR. As a country which primarily depends on trade to assert control over global economy and politics, the IO is of great importance for China since all of its trade passes through it. China acquired has acquired the lease Hambantota port in Sri Lanka for 99 years which has caused alarm to India due to Beijing's growing strategic and economic influence in the IOR (Panda, 2017). As its location is beside India, it might allow China to keep close tabs on India as moving towards operationalizing the port for military purpose. Furthermore, under the Belt and Road Initiative (BRI) which is known as "One Belt, One Road," China got the scope to develop the Gwadar deep seaport in Pakistan in 2017. If this project is implemented, longstanding China's reliance on Malacca will be lessened (James, 2017). There is even a suspicion about possible naval base in Gwadar which would give China intelligence capabilities in the waters of IOR adjacent to the Strait of Hormuz which is not a good news for India and USA (Grare, 2018; Ali et al., 2019).

China's growing naval ties with Myanmar, Maldives and Bangladesh are the indications of its inclination for domination over IO through strategic partnership with other countries. All three littoral states are of great importance to IOR politics due to their geo-strategic locations. China is constructing a deep-sea porta and a Special Economic Zone (SEZ) in Myanmar (Wadlow, 2018). The recent regime change in Myanmar has facilitated this partnership in deeper level. February 2018, China sent 11 warships to support Maldives in a time of crisis (Reuters Staff, 2018a). Lastly, over the years, China has developed military relations with Bangladesh, the closest neighbors of India which has become grave concern for India.

In 2017, China officially opened its first military base in Djibouti of East Africa, which is of strategic importance to USA as well. This military base is considered to be a gamechanger for 
China since this would grant China an access to strategic route that links the world to Europe. USA already has a naval expeditionary base there. China's capability to open military base in such a place is counted a threat to USA's power and presence in this location (Blanchard, 2017; Wang, 2018; Ahmad et al., 2019).

According String of Pearls' theory, the aforementioned networks, investment and partnership refers to China's way of converging between military and commercial facilities in countries falling on the IO between the Chinese mainland and Port Sudan (Dabas, 2017). In the long run, this means to encircle India from geo political strategic locations. Chinese President Xi Jinping is found to be extremely determined to translate the 'Chinese dream' into reality by transforming China into a Superpower by 2050 (Chai \& Chai, 2013). To implement this plan, China needs to firmly establish dominance over IOR. The BRI, which intends to integrate the IOR with Europe, Middle East and Africa, is China's major ambitious project on the way to claim that control on IOR. By these six 'economic corridors,' China will definitely increase influence in Asia and Africa, South America and the eastern Mediterranean (Siraj et al., 2019; Ziegler, 2020; Usman et al., 2021). The power and network China would establish through this initiative is far more than the trade boost. It will have a long last consequence of military interest and, certainly will impact the dynamic of politics over IOR. Its potential threat could be fathomed by observing India's anxiety over this project with a prediction that in the near future, China will use this network to develop conflicting and competing interests against India in IOR regions.

\subsection{Implications for Pakistan}

Despite being a key littoral state of the IO, Pakistan was excluded from the 'Indian Ocean Rim Association' (IORA) (Bastos, 2018). This exclusion also implies Pakistan's absence from diplomacy and network with other stakeholders of IOR in this international platform. Pakistan's historical rivalry with India and the USA's dissatisfaction with Pakistan's performance and role in global war on terror have been major factors behind this exclusion (Salim et al., 2018). In the intense Indo-Chinese rivalry in the IO, Pakistan has become a part due to its partnership with China, particularly through the BRI (Jaffery, 2019). To safeguard the maritime routes of the BRI, more specifically the CPEC routes, initially 2 warships were given by China to Pakistan Navy to patrol the IO (Baloch, 2017). Later, the number of warships and nuclear capable submarines were increased to safeguard maritime security (Romaniuk \& Burgers, 2019). Under this initiative, satellite monitoring station will be constructed to keep a vigilant eye on all BRI/CPEC activities in the IO (Azmat, 2016).

Historically, the relations amongst India and Pakistan have remained tense and hostile since the British partition of Sub-Continent. Since 1947 to date, both states, have tried to manage bilateral ties, not resolve the longstanding dispute over 'Jammu and Kashmir.' The key to peace and stability of the region is heavily dependent upon friendly ties between the two neighboring states specially in the geo-strategic central stage of the world. Pakistan needs to reexamine its role in the context of growing polarizations of IOR and calculate the cost of going against USA and keeping sour relation with India and the benefit of taking anti USA-India stance. It needs to reshape its diplomatic strategies to become member of international platforms of IOR. 
Pakistan also needs to find out ways to be a good partner to China, at the same time, not to be categorized as anti-USA in IOR politics.

Despite being interlocked in a regional hegemonic competition, the volume of the bilateral trade between India and China exceeds over \$100 billion (Saibal, 2019). Pakistan must also understand that 'complex economic interdependence' vis-à-vis India is the only way to ensure peace, as it will create absolute gains, a win-win situation. Thus, it must create conducive condition so that trade and commerce ties between the two neighboring states flourishes (Rashid \& Hilali, 2020).

Besides from improving trade relations, Pakistan must ensure peace, stability and security within its jurisdiction. More importantly, Pakistan must ensure that the CPEC is developed as planned on time. Thus, on priority basis, Pakistan should upgrade military/paramilitary forces as well as its naval capabilities and show all good intention to the combat terrorism in neighbours in aligned with the USA's interest.

Pakistan also needs to improve its relations with the Arab World, in particular the 'Gulf Cooperation Council (GCC)' states. Historically, Pakistan had amicable ties with these Gulf states. However, Pakistan's relationship with these Gulf states deteriorated after it entangled itself in the Afghan Jihad of the 1980's, which led to domestic instability and insecurity which amplified in the form of terrorism after 9/11. On the other hand, India greatly capitalized from this situation, it made serious inroads in the oil-rich region. Though, the new regime has taken up various steps to mend relations with the GCC in particular, Pakistan must go an extra mile and fix its bond with the Arab Muslim brethren, as it will help Pakistan greatly in the geoeconomic and geopolitical domains (Zikriya et al., 2019).

\section{Conclusion}

It is needless to tell that IOR will be battleground for superpowers and their oppositional blocs in coming days. In the scripts of this battle, trade relations will converge with hidden or direct military interests among the superpowers and their allies. In the last decade and a half, both India and China have expedited their respective campaigns in the IOR to ensure their dominance of the region. They did so by forming alliances and acquiring strategic assets, which in turn has greatly polarized an already politically volatile region. The day by day growing competition between the two states, and the added support of key players; the US supporting India and China aggressively forming coalition with key geo-strategic states such as Pakistan and the five 'Central Asian Republics,' is tilting the IOR towards potential conflict among multi stakeholders.

Amidst all these potential conflicts and ever-increasing tensions in the IOR, Pakistan needs to navigate these troubled waters very carefully. It is in neither in a position to outrightly defy and stand against the world's hegemon, the US - a former key ally - nor can it backout of the commitments it made to its new strategic partner and trusted all-weather friend, China. Furthermore, it must be open to dialogue with all competing parties and persistent in peaceful negotiation for claiming its member ship of the platforms related to IOR and good relations 
with India and the USA. Pakistan must capitalize opportunities from China on one hand, keep trustworthy relationship with the USA and be open for resolving all conflicts with India through dialogue and mutual cooperation. Only then Pakistan can be benefited from the polarization and development of this interdependent trade networks in IOR.

\section{Declaration of conflict of interest}

The author(s) declared no potential conflicts of interest(s) with respect to the research, authorship, and/or publication of this article.

\section{Funding}

The author(s) received no financial support for the research, authorship and/or publication of this article.

\section{References}

Ahmad, S., Gull, A., \& Irfan, S. (2019). Sino-African relations: Economic opportunities and challenges for China. Liberal Arts and Social Sciences International Journal (LASSIJ), 3(1), 61-73. https://doi.org/10.47264/idea.lassij/3.1.6

Ahmad, S., Syed, A., Bhutta, M. M. (2020). Indian inclusion in CPEC: A path to Indo-Pak threat reduction via complex interdependence. Liberal Arts and Social Sciences International Journal (LASSIJ), $\quad 3(2), \quad 11-19$. https://doi.org/10.47264/idea.lassij/3.2.2

Ali, S. M. (2020, December 1). The US-China strategic rivalry and its implications for Pakistan. Stimson. https://www.stimson.org/2020/the-u-s-china-strategic-rivalryand-its-implications-for-pakistan/

Ali, R., Ali, I., \& Ullah, S. (2019). SCO as a passage to regional security: Future developments and opportunities for Pakistan. Liberal Arts and Social Sciences International Journal (LASSIJ), 3(1), 19-29. https://doi.org/10.47264/idea.lassij/3.1.3

Ansari, B. (2019, November 25). Indian Ocean: A great game for strategic and nuclear supremacy. South Asian Strategic Stability Institute. http://sassi.org.pk/indian-oceana-great-game-for-strategic-and-nuclear-supremacy/

Aliasgary, S., \& Ekstrom, M. (2021, October 21). Chabahar Port and Iran's strategic balancing with China and India. The Diplomat. https://thediplomat.com/2021/10/chabahar-portand-irans-strategic-balancing-with-china-and-india/

Azmat, Z. (2016, October 9). Pakistan and China developing satellite to monitor CPEC route. The News. https://www.thenews.com.pk/print/155917-Pakistan-and-Chinadeveloping-satellite-to-monitor-CPEC-route

Baloch, B. (2017, January 15). China hands over two ships to Pakistan for maritime security. Dawn. http://www.dawn.com/news/1308491

Bastos, M. (2018, May 4). Pakistan's foreign policy towards the Indian Ocean Region. Pakistan Politico. http://pakistanpolitico.com/pakistans-foreign-policy-towards-theindian-ocean-region/ 
Blanchard, B. (2017, August 1). China formally opens first overseas military base in Djibouti. Reuters. https://www.reuters.com/article/us-china-djibouti-idUSKBN1AH3E3

Brookings. (2017, December 21). Experts on Trump's National Security Strategy (NSS). https://www.brookings.edu/research/brookings-experts-on-trumps-national-securitystrategy/

Chai, W., \& Chai, M. (2013). The meaning of Xi Jinping's Chinese dream. American Journal of Chinese Studies, 20(2), 95-97. https://www.jstor.org/stable/44289022

Chaudhury, D. R. (2017, May 26). OBOR: India, Japan come up with AAGC to counter China's OBOR. The Economic Times. https://economictimes.indiatimes.com/news/economy/policy/india-japan-come-upwith-aagc-to-counter-chinas-obor/articleshow/58846673.cms?from $=\mathrm{mdr}$

Chinoy, S. R. (2019, November 7). China remains wary of the Quad and its future contours. The Indian Express. https://indianexpress.com/article/opinion/columns/indiaquadrilateral-cooperation-dialogue-china-japan-us-6106772/

Clinton, H. (2011, October 11). America's pacific century. Foreign Policy. https://foreignpolicy.com/2011/10/11/americas-pacific-century/

Cordesman, A. H., \& Toukan, A. (2014, August). The Indian Ocean Region: A strategic net assessment. Center for Strategic and International Studies. A report of CIS Burke Chair in Strategy, with the assistance of D. Dewit and G. Berntsen. https://csiswebsite-prod.s3.amazonaws.com/s3fs-

public/legacy files/files/publication/140814_Cordesman_IndianOceanRegion_Web. pdf

Dabas, M. (2017, June 23). Here is all you should know about 'String of Pearls', China's Policy to encircle India. India Times. https://www.indiatimes.com/news/india/here-is-allyou-should-know-about-string-of-pearls-china-s-policy-to-encircle-india$\underline{324315 . h t m l}$

Dombrowski, P., \& Winner, A. C. (2014). The Indian Ocean and US grand strategy: Ensuring access and promoting security. Georgetown University.

Farr, G. (2017, July 10). Pakistan's role in China's One Belt One Road initiative. EInternational Relations. https://www.e-ir.info/2017/07/10/pakistans-role-in-chinasone-belt-one-road-initiative/

Farid, F. (2020, Feburary 7). Why Pakistan needs a comprehensive Indian Ocean policy. Fletcherforum. http://www.fletcherforum.org/home/2020/2/7/why-pakistan-needs-acomprehensive-indian-ocean-policy

Ford, L. W. (2020, May). The Trump administration and the "Free and Open Indo-Pacific". Brookings. https://www.brookings.edu/research/the-trump-administration-and-thefree-and-open-indo-pacificl

Grare, F. (2018, July 31). Along the road: Gwadar and China's power projection. Carnegie Endowment for International Peace. https://carnegieendowment.org/2018/07/31/along-road-gwadar-and-china-s-powerprojection-pub-77217

Glosserman, B. (2020, September 1). 'Debt trap' diplomacy is a card China seldom plays in Belt and Road Initiative. The Japan Times. https://www.japantimes.co.jp/opinion/2020/09/01/commentary/debt-trapdiplomacy-bri-china/ 
Grieco, K. A. (2018). The 2018 National Defense Strategy: Continuity and Competition. Strategic Studies Quarterly, 12(2), 3-8. https://www.jstor.org/stable/26430813

Gul, A., Hussain, M., Imran, S., Rehman, A. U., \& Haider, S. A. (2021). Assessing various opportunities and challenges in India-US strategic partnership. Journal of Legal, Ethical and Regulatory Issues, 24(S1), 1-14. https://www.abacademies.org/articles/assessing-various-opportunities-andchallenges-in-indiaus-strategic-partnership-12461.html

Hannah, H. I. (2019, April 1). The great game moves to sea: Tripolar competition in the Indian Ocean Region. Texus National Security Review. https://warontherocks.com/2019/04/the-great-game-moves-to-sea-tripolarcompetition-in-the-indian-ocean-region/

Hassan, M. A. (2019). Growing China-India competition in the Indian Ocean: Implications for Pakistan. Strategic Studies, 39(1), 77-89. https://doi.org/10.2307/48544289

Hindustan Times. (2021, Nov 30). India refuses to support China's Belt and Road project at SCO meet. Hindustan Times. https://www.hindustantimes.com/india-news/indiadoesn-t-join-sco-members-in-endorsing-china-s-belt-and-road-project/storyCBH22ODWVImRFpwkkhehWI.html

Hornat, J. (2016). The power triangle in the Indian Ocean: China, India and the United States. Cambridge Review of International Affairs, 29(2), 425-443. https://doi.org/10.1080/09557571.2014.974507

Hornby, L. (2018, August 8). Mahathir Mohamad warns against 'New Colonialism' during China visit. Financial Times. https://www.ft.com/content/7566599e-a443-11e8-8ecf$\underline{\text { a7ae1beff } 35 b}$

Idrees, M., Naazer, M. A., Ashfaq, S. (2017). Conflicts and conflict management in SAARC: Assessing challenges and the way forward. Liberal Arts and Social Sciences International Journal (LASSIJ), 1(2), 1-11. https://doi.org/10.47264/idea.lassij/1.2.1

Jaffery, S. A. Z. (2019, February 15). Pakistan in the Indo-Pacific: Caught in the geopolitical crossfire. South Asian Voices. https://southasianvoices.org/pakistan-in-the-indopacific-caught-in-the-geopolitical-crossfire/

Jaishankar, D. (2016, September 12). Indian Ocean Region: A pivot for India's growth. Brookings. https://www.brookings.edu/opinions/indian-ocean-region-a-pivot-forindias-growth/

James, T. (2017, March 8). Can China overcome the Malacca Dilemma through OBOR and CPEC? Global Risk Insights. https://globalriskinsights.com/2017/03/chinaovercome-malacca-dilemma-obor-cpec/

Jeffrey, C. (2019, January 15). Why the Indian Ocean Region might soon play a lead role in world affairs. Australia India Institute. https://www.aii.unimelb.edu.au/blog/whythe-indian-ocean-region-might-soon-play-a-lead-role-in-world-affairs/

Kowalski, J.M. (2019). Sailing the Indian Ocean in Ancient Times. Angles: New Perspectives on the Anglophone World, 9. https://doi.org/10.4000/angles.800

Mahan, A. (1987). The Indian Ocean in world politics: Reflections on its future By Prasanta Sen Gupta. India Quarterly, 43(3-4), 195-212. https://doi.org/10.1177/097492848704300301

Panda, J. (2017). The Asia-Africa growth corridor: An India-Japan arch in the making. Focus 
Asia: $\quad$ Perspective $\quad \& \quad$ Analysis, $\quad 21, \quad 1-11$. https://isdp.eu/content/uploads/2017/08/2017-focus-asia-jagannath-panda.pdf

Panikkar, K. M. (1945). India and the Indian Ocean. Macmillan. http://www.fletcherforum.org/home/2020/2/7/why-pakistan-needs-acomprehensive-indian-ocean-policy

Rashid, Z. \& Hilali, A. Z. (2020). Geo-Politics of Most Favoured Nation (MFN) status under the WTO and future of trade between India-Pakistan. Liberal Arts and Social Sciences International Journal (LASSIJ), 4(1), 54-65. https//:doi.org/10.47264/idea.lassij.4.1.6

Rehman, A. U., Hakim, A., Khan, K., \& Khan, I. U. (2018). Role of CPEC in development of trade, transport and economy of Pakistan. Romanian Journal of Transport Infrastructure, 7(1), 77-92. https://doi.org/ 10.2478/rjti-2018-0005

Reuters Staff. (2018a, February 20). Chinese warships enter East Indian Ocean amid Maldives tensions. Reuters. https://www.reuters.com/article/us-maldives-politics-chinaidUSKCN1G40V9

Reuters Staff. (2018b, August 5). U.S. pledges nearly $\$ 300$ million security funding for IndoPacific Region. Reuters. https://www.reuters.com/article/us-asean-singapore-usasecurity-idUSKBN1KP022

Romaniuk, S. N., \& Burgers, T. (2019, January 26). Pakistan's new generation of Chinese warships. The Diplomat. https://thediplomat.com/2019/01/pakistans-newgeneration-of-chinese-warships/

Sagar Mala-Concept \& Objectives. (n.d.). Ministry of Shipping, Government of India. http://sagarmala.gov.in/about-sagarmala/vision-objectives

Saibal, D. (2019, June 7). India-China Trade to Touch \$100 Billion-Mark this Year. The Times of India. https://timesofindia.indiatimes.com/business/india-business/india-chinatrade-to-touch-100-billion-mark-this-year/articleshow/69691004.cms

Salim, A., Semetko, H. A., Zehra, S. (2018). Pak-US Strategic Partnership and Challenge of Internal Radical Symbiosis. Liberal Arts and Social Sciences International Journal (LASSIJ), 2(1), 57-64. https://doi.org/10.47264/idea.lassij/2.1.7

Sengupta, A. (2020). The oceans as new regions: emerging narratives and the Bay of Bengal. Journal of the Indian Ocean Region, 16(3), 229-243. https://doi.org/10.1080/19480881.2020.1820690

Siraj, U., Saqib, N. U., Naazer, M. A. (2019). Eurasian Integration and China's BRI: Opportunities and Challenges. Liberal Arts and Social Sciences International Journal (LASSIJ), 3(1), 93-107. https://doi.org/10.47264/idea.lassij/3.1.9

Tabrizi, A. B., \& Dave, A. (2017, March 9). Chabahar: The key to a strategic partnership between India and Iran? The Interpreter. https://www.lowyinstitute.org/theinterpreter/chabahar-key-strategic-partnership-between-india-and-iran

Thakker, A. (2018, October 17). A rising India in the Indian Ocean needs a strong Navy. Centre for Strategic and International Studies. https://www.csis.org/npfp/rising-indiaindian-ocean-needs-strong-navy

Usman, S. M. \& Lyu, Z. (2021). Sino-Africa relations: Gradual changes in Chinese foreign strategy towards African countries. Liberal Arts and Social Sciences International Journal (LASSIJ), 5(1), 154-167. https://doi.org/10.47264/idea.lassij/5.1.11

Wadlow, T. (2018, June 4). An overview of the \$9bn China-backed proposal for Myanmar's Kyaukpyu Port.

Construction

Global. 
https://constructionglobal.com/infrastructure/overview-dollar9bn-china-backedproposal-myanmars-kyaukpyu-port

Wang, M. (2018, April 13). China's strategy in Djibouti: Mixing commercial and military interests. Council on Foreign Relations. https://www.cfr.org/blog/chinas-strategydjibouti-mixing-commercial-and-military-interests

Yaqoob, S. \& Sattar, N. (2021). Aid and irritants in Pak-US relations in the wake of 9/11 incident. Liberal Arts and Social Sciences International Journal (LASSIJ), 5(1), 266278. https://doi.org/10.47264/idea.lassij/5.1.18

Younus, K. (2020). Strategic Convergence and Competition in the Indo-Pacific Region: Policy Options for Pakistan. Margalla Papers, XXIV(1), 80-95. https://margallapapers.ndu.edu.pk/site/article/view/39

Zaidi, S. M. S., Saud, A., \& Ashher, S. (2020). US initiatives to contain China's Rise: Post 2008's economic crisis. International Review of Social Sciences, 8(9), 18-33. https://irss.academyirmbr.com/papers/1599211699.pdf

Ziegler, D. (2020, February 6). China wants to put itself back at the centre of the world. The Economist. https://www.economist.com/special-report/2020/02/06/china-wants-toput-itself-back-at-the-centre-of-the-world

Zikriya, Khan, N., \& Salim, A. (2019). Middle East Dilemma: Pakistan's Role as Mediator for Conflict Resolution. Liberal Arts and Social Sciences International Journal (LASSIJ), 3(1), 9-18. https://doi.org/10.47264/idea.lassij/3.1.2 